\title{
Výsledky nedestruktivních metod podporují rozhodování o riziku
}

\section{Results of Non-Destructive Methods Support Decision on Risk}

Dana Procházková*, Václav Svoboda

Prediest s.r.o

\begin{abstract}
Abstrakt
Současné poznání fyziky a technologií ukazuje, že stav materiálů technických zařízení, komponent i celých technických děl je ovlivňován podmínkami, ve kterých jsou provozovány a také časem, který plyne od jejich zhotovení. Pro zajištění bezpečnosti lidského systému (tj. i technického díla a jeho okolí) je třeba proto také sledovat rizika spojená $\mathrm{s}$ degradačními procesy technických zařízení a správně je vypořádat. $\mathrm{K}$ danému cíli slouží data, která poskytují nedestruktivní metody měření stavu materiálu technických zařízení. Na základě fyzikální interpretace výsledků dvou vybraných nedestruktivních metod, článek ukazuje, že sledované metody jsou významným nástrojem pro zvýšení věrohodnosti rozhodování o riziku, jehož zdrojem je technické zařízení. Tento př́íspěvek byl prezentován v rámci 28 . ročníku mezinárodní vědecké konference Soudního inženýrství ExFoS 2019.
\end{abstract}

Klíčová slova: technická zařízení, degradace materiálu, riziko, bezpečnost, nedestruktivní metody měřní.

\section{1. ÚVOD DO PROBLEMATIKY}

Současné poznání ukazuje, že pro bezpečí a rozvoj lidské společnosti je nezbytná bezpečnost technických děl. V práci se soustředíme jen na dílčí, ale důležitou část technických děl, a to bezpečnost technických zařízení. Jelikož bezpečnost závisí na řízení rizik [1], tak soustředíme pozornost na řízení rizik technických zařízení, a to na podklady podporující správné rozhodnutí o riziku, aby se v zájmu bezpečnosti přijala správná opatření pro nakládání s předmětným technickým zařízením.

Dle práce [1] riziko v současném inženýrském pojetí znamená pravděpodobnou velikost škod, ztrát a újmy na chráněných aktivech, kterou způsobí pohroma (škodlivý jev) o normativně

\begin{abstract}
Current knowledge of physics and technology shows that the conditions of the technical equipment, components, materials and even the whole technical facilities are influenced by the conditions in which they operate, and also the time that follows from their construction. In order to ensure the human system safety (i.e. also technical facility and its surroundings), it is necessary also, therefore, to monitor the risks associated with degradation processes of technical equipment and properly to cope with them. For this target, they are used data that provide non-destructive methods for measuring the condition of the material of technical equipment. On the basis of the physical interpretation of the results of the two selected non-destructive methods, the article shows that followed methods are an important tool for enhancing the decision credibility on the risk, the source of which is technical equipment. The paper was presented during the $28^{\text {th }}$ International Scientific Conference of Forensic Science ExFoS 2019.
\end{abstract}

Keywords: technical equipment, material degradation, risk, safety, nondestructive measurement methods.

určené velikosti (nazývané ohrožení), která je normovaná na jednotku plochy a jednotku času, tj. jde o míru nepřijatelných dopadi̊ způsobených pohromou o velikosti rovné hodnotě ohrožení. Riziko je inherentní součástí našeho světa, a proto se na něho zaměřuje legislativa, normy a standardy. Např. novelizace mezinárodní normy ISO 9000, vydaná v ČR v r. 2016, vyžaduje analýzu rizik v souvislosti se zajišt'ováním kvality procesů a produktů ve firmách, které usilují o certifikaci či re-certifikaci systému řízení kvality. Předmětná norma odkazuje na další normy: ČSN ISO 31000 Management rizik - principy a směrnice; ČSN EN 31010 Management rizik - Techniky posuzování rizik atd.

Při práci s riziky je třeba riziko identifikovat, analyzovat, ohodnotit, posoudit jeho závažnost, řídit a vypořádat ve prospěch 
stanoveného cíle; ve složitém světě existuje řada faktorů, které určují velikost rizika [1]. Podstatnou roli hraje hodnocení rizika, a hlavně disponibilní data pro jeho provedení. Hodnocení rizika je proces, který je podstatnou složkou ř́zení a regulace a významnou složkou rozhodování, a proto jeho správnost a věrohodnost jsou důležité.

Dle [2] hodnocení rizika je metoda stanovení hodnoty rizika $\mathrm{v}$ dané hodnotové stupnici. Podle konkrétní povahy předmětu hodnocení metoda spočívá ve srovnání s kritériem nebo souborem kritérií, která představují měřítka, určující, poznávací a rozlišovací znaky pro srovnávání. Některá z kritérií bývají dokonce jen kvalitativní a mnohá z nich jsou nesouměřitelná. Struktura procesu hodnocení závisí na dále uvedených faktorech:

- co je hodnoceno?

- kdy je hodnoceno, resp. vzhledem k jakému časovému okamžiku je hodnoceno?

- jak, tj. na základě jakých kritérií, je hodnoceno?

Jak bylo řečeno, hodnocení představuje uplatnění jistých kritérií, hodnotících funkcí nebo preferencí. To znamená, že když soubor kritérií nebo pořadí kritérií změníme, tak není výsledek stejný.

Pro hodnocení, tj. určení míry rizika (a následně i míry bezpečnosti) se podle potřeby používají:

- alfabetické stupnice (např. podle velikosti dopadu je riziko: zanedbatelné, malé, střední, velké, extrémní; nebo podle četnosti výskytu je riziko: nepravděpodobné, možné, časté, velmi časté, jisté),

- indikátory (číselné hodnoty pravděpodobnosti výskytu dopadu při realizaci rizika nebo číselné hodnoty velikosti dopadu při realizaci rizika), které jsou jistým způsobem vázané na uvedenou alfabetickou stupnici (např. pro pravděpodobnost výskytu dopadu prri realizaci rizika: 1 - výskyt je vyloučený, 2 - výskyt je nepravděpodobný, 3 - výskyt je možný, 4 - výskyt je velmi pravděpodobný, 5 - výskyt je téměř jistý; pro velikost dopadu při realizaci rizika: 1 - škody a ztráty jsou zanedbatelné, 2 - škody a ztráty jsou nízké, 3 - škody a ztráty jsou střední, 4 - škody a ztráty jsou vysoké, 5 - škody a ztráty jsou extrémní). Závažnost (významnost) rizik měřených indikátory se obvykle určuje pomocí rozhodovacích matic, ve kterých se skóruje pravděpodobnost výskytu dopadů a velikost ztráty způsobené dopady nebo pomocí prostého součinu indikátoru vyjadřujícího výši pravděpodobnosti výskytu dopadu a indikátoru vyjadřujícího velikost ztrát (např v uvedené souvislosti jsou možnosti 1 až 25 a lze použít klasifikaci: je-li součin menší než 5, je riziko nevýznamné; je-li součin mezi 6a 10, je riziko malé; je-li součin mezi 11 a 15 je riziko střední; je-li součin mezi 16 a 20 je riziko velké; je-li součin nad 20, je riziko extrémně velké),

- výsledky přesného stanovení nebo změření konkrétních škod a ztrát [1] (pro potřeby vyjednávání s riziky jsou zjištěné hodnoty srovnávané s prahovými hodnotami, např přijatelné - škoda je menší než 0.01 měsíčního rozpočtu, nepřijatelné - škoda je větší nebo rovna 0.1 měsíčního rozpočtu a podmíněně přijatelné, když hodnoty jsou v mezi limitami (místo peněz lze použít hodnoty koncentrace škodlivých látek, množství odpadu, stupeň neplnění požadavků apod.)
Hodnocení má několik kvalitativních úrovní, srovnání se provádí vůči limitu danému konkrétní hodnotou, limitu danému konkrétní křivkou nebo konkrétním prostorovým útvarem v př́ípadě vícerozměrných problémů. U složitějších případů hodnocení se používají prediktivní metody, které jsou nejčastěji založeny na použití:

- exaktních výpočtů,

- statistických formulí,

- experimentálního sledování a matematického modelování,

- expertních př́stupů, založených na odhadech, analogiích a zkušenostech,

- skórování veličin, tj. u nesouměřitelných veličin se používají metody multikriteriální analýzy, tj. např. rozhodovací tabulky.

Pro určité úkoly praxe, kterými je např. zajištění bezpečného technického zařízení, postačí často sledovat jen dopady dílčího rizika určitého procesu (např. stárnutí či opotřebení). Přitom není třeba znát jeho velikost zcela přesně, postačí pouze hodnota spolehlivého indikátoru (např. určitého fyzikálního parametru), na jehož základě je možno posoudit, zda v daném konkrétním případě je riziko spojené $\mathrm{s}$ opotřebením technického zařízení přijatelné, podmíněně přijatelné, anebo nepřijatelné. Tento postup založený na interpretaci výsledků měření fyzikálních jevů je v technické praxi běžně využíván.

Znalosti fyziky a technologií ukazují, že stav materiálů technických zařízení, komponent i celých technických děl je ovlivňován podmínkami, ve kterých jsou provozovány a také časem, který plyne od jejich zhotovení. Problematika řízení stárnutí materiálů, z nichž jsou zhotovena technická zařízení, technické komponenty i celá technická díla, patří proto do základních technologických oborů $[3,4]$; a proto se na ni v práci soustřed’ujeme a sledujeme zdroje rizik, které předurčují chování materiálů technických zařízení.

Z důvodu zajištění bezpečnosti technických zařízení, komponent i celých technických děl je proto třeba sledovat rizika spojená s degradačními procesy a pomocí optimální údržby, optimálního režimu provozu či včasné výměny opotřebovaných částí udržovat přijatelnou úroveň bezpečnosti, tj. bezpečnost je nutno řídit.

Pro řízení jsou nutná data, která se opatřují pomocí nedestruktivních metod měření stavu materiálu [5-9]. Předmětných metod je celá řada a každá z metod má své hranice použitelnosti; dle práce [9] neexistuje metoda, která by umožňovala zjistit všechny závady na matriálu. Proto je nutné používat kombinace metod a umět správně interpretovat výsledky.

Předložená práce ukazuje dva konkrétní př́klady výsledků dvou vybraných nedestruktivních metod. Jsou sledovány dopady rizika, které souvisí s opotřebením technického zařízení v důsledku stárnutí a podmínek, ve kterých je zařízení provozováno.

\section{Bezpečnost technických zařízení}

Bezpečnost technických zařízení závisí na mnoha položkách, tj. na materiálu, způsobu zhotovení, způsobu provozu a provozních podmínkách [10-13]. Pro její zajištění je třeba sledovat všechna rizika spojená s uvedenými položkami a řídit je tak, aby sledované zařízení pracovalo po celou dobu životnosti bezpečně, tj. spolehlivě 


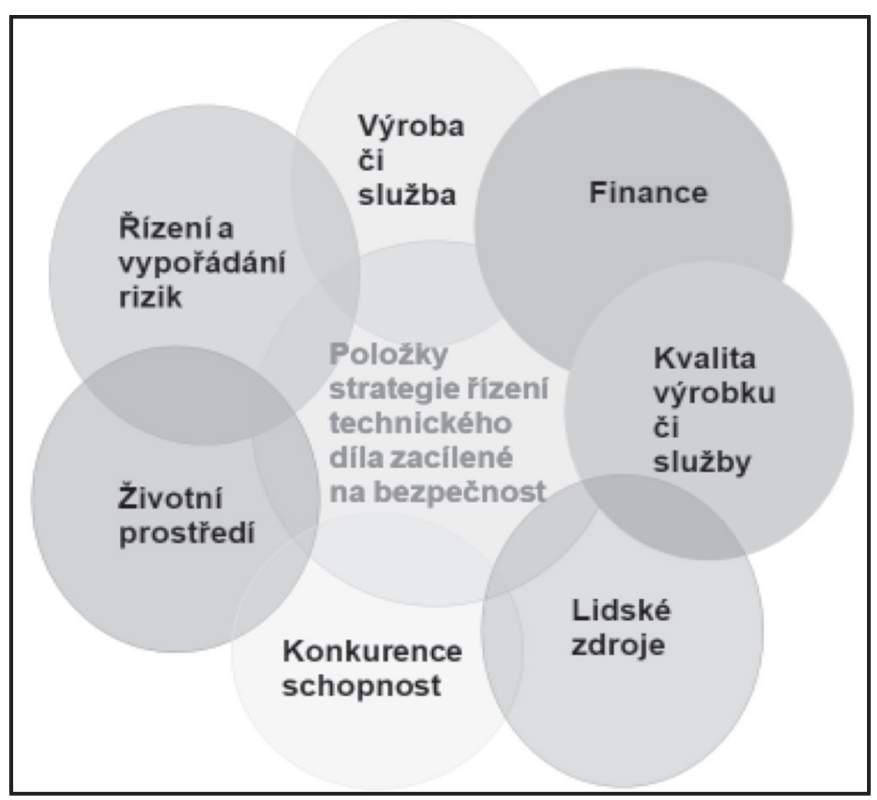

Obr. 1 Položky, které musi sledovat strategie řizeni technického díla zacílená na bezpečnost.

Fig. 1 Items that need to be respected by strategy of management of technical facility aimed to safety.

plnilo funkce $\mathrm{v}$ požadované kvalitě, $\mathrm{v}$ požadovaném množstvî a $\mathrm{v}$ požadovaném čase, a při svých kritických podmínkách neohrozilo ani sebe, ani své okolí [10-13].

Na základě šetření spojených se zpracováním prací [1,10-13] se $\mathrm{v}$ technickém sektoru často zvažuje jen kontext technického zařízení, technické komponenty, technického díla nebo kontext podniku, který technické dílo spravuje a $\mathrm{v}$ řadě př́ípadů jen kontext výrobního zařízení. S ohledem na bezpečí a rozvoj lidské společnosti, tj. z veřejného zájmu je však třeba zvažovat kontext širší, tj. i okolí sledované technické entity. Přitom si je třeba uvědomit, že užitek $\mathrm{z}$ technického díla $\mathrm{v}$ dlouhodobé perspektivě není dán jen výkonem, tj. množstvím výrobků, energií či služeb, ale i tím, že bude zabráněno ztrátám způsobeným haváriemi.

Práce [1] uvádí faktory, které je nutno sledovat při strategickém řízení bezpečnosti technických entit; obr. 1. Oblast výroby a služeb dále závisí na technických zařízeních, obsluze, podmínkách a procesech výroby, které jsou opět vzájemně propojenými otevřenými systémy. Samotný stav technického zařízení závisí na materiálu, ze kterého bylo zařízení zhotoveno, způsobu výroby a konstrukce, na provozních podmínkách a na způsobu, jak se s ním zachází, tj. kvalita a způsob údržby a provádění oprav.

$\mathrm{Z}$ důvodu složitosti problému technických děl z pohledu potřeb lidské společnosti, tj. veřejného zájmu není pro lidskou společnost ideální, aby se technická díla, objektová i sít'ová orientovala jen na výkon. Jestliže není brán ohled na veřejná aktiva a kritická aktiva technického díla, a dojde $\mathrm{k}$ havárii nebo selhání technických děl, tak př́klady v pracích [10-12] ukazují, že často vznikají ztráty na lidských životech uvnitř i vně technického díla, majetku, životním prostředí a v případě těch kritických děl i velké ekonomické ztráty v území o menším či větším rozměru, které jsou často střednědobé až dlouhodobé, tj. značně ovlivňující rozvoj lidské společnosti a zasaženého území. Proto je třeba při řízení technických děl dbát především na prevenci ztrát [10], kterou lze dosáhnout jen cíleným kvalifikovaným řízením rizik.
V případě technických zařízení, komponent i celých technických děl jde o zajištění jejich bezpečnosti v integrálním smyslu, což lze dosáhnout jen cíleným řízením všech prioritních rizik, do kterých patř́i i rizika spojená s jejich materiálem $[1,10-12]$.

Aby se zajistila integrální bezpečnost, tak musí být věnována péče i bezpečnosti dílčích částí, tj. i u dílčích částí je nutno řídit rizika. To znamená, že musí být sledována a řízena rizika jednotlivých technických zařízení. Zdroje těchto rizik jsou rozmanité a vyžadují specifická posouzení [10-12]. V článku sledujeme dopady rizika, které souvisí s opotřebením technického zařízení.

\section{Metody sledování rizik technických zařízení}

Diagnostické metody [3-9] umožňují poznat současný stav technických zařízení a na základě toho určit jejich možná chování $\mathrm{v}$ dalším čase. V provozu mají hlavní cenu nedestruktivní metody. Používají se v rámci permanentního monitoringu, při intervalových měření i nárazově při problémech.

Cílem nedestruktivních metod dle údajů v pracích [3-9] je:

- zjistit celistvost technického zařízení, což garantuje jeho spolehlivost,

- předejít selhání technického zařízení vlivem poruch, čímž se předchází úrazům, zajišt'uje se ochrana investic a jejich návratnost,

- spokojenost uživatelů zařízení i služeb, které tato zařízení poskytují,

- podpoření goodwill provozovatele,

- zlepšení designu technického zařízení,

- zlepšení ŕízení výrobních procesů,

- snížení výrobních nákladů.

Rozlišuje se šest hlavních kategorií nedestruktivních metod: vizuální; radiační; magneticko-elektrické; mechanické vibrace; termální; a chemické / elektrochemické. Podle údajů v pracích [3-9] a zkušeností autorů je každá metoda charakterizovaná dále uvedenými pěti faktory:

1. Předmět sledování při testu (tlak, teplota, průtok, výkon, chování rentgenových paprsků, chování ultrazvukových vln, chování termálního zárené, chování intenzity magnetického pole apod.).

2. Sledovaný fyzikální parametr (deformace, napětí, tvrdost, útlum rentgenových paprsků, útlum ultrazvukových vln, odraz ultrazvuku, intenzita magnetického pole, koncentrace poruch apod.).

3. Zařízení používané k detekování nebo snímání výsledných signálů (fotoemulze, piezoelektrický krystal, indukční cívka apod.).

4. Veličina použitá $\mathrm{k}$ indikování nebo zaznamenání signálů (odchylka, stopa na oscilografu, průběh magnetogramu, termogramu, radiogramu, konfigurace v ploše či prostoru apod.).

5. Podklad pro interpretaci výsledků (přímá nebo nepř́má indikace kvalitativní nebo kvantitativní změny).

Cílem každé metody je zjistit údaje o jednom parametru materiálu nebo o několika parametrech materiálu:

1. Existence diskontinuit $\mathrm{v}$ materiálu a jejich rozdělení (trhliny, dutiny, městky, štěpení, dělení na vrstvy apod.). 
2. Charakter struktury materiálu (krystalická, amorfní, velikost zrn, mezilamelární defekty, segregace, poruchy apod.).

3. Velikost a charakteristika poruch materiálu (povrchové, pronikající dovnitř, šiřka, tloušt'ka, průměr, spáry, popraskání apod.).

4. Fyzikální a mechanické vlastnosti diskontinuit (odrazivost, vodivost, modul pružnosti, rychlost zvuku apod.).

5. Složení a chemická analýza materiálu (identifikace slitin, nečistoty, př́měsi, rozložení nečistot apod.).

6. Pnuti a dynamická odezva materiálu (zbytkové pnutí, narůstání trhlin, opotřebení, vibrace apod.).
7. Výskyt termálních, magnetických, elektrických a jiných anomálií v materiálu.

Ze sledovaných zdrojů i zkušeností autorů vyplývá, že žádná metoda neodhalí všechny defekty v materiálu. Pro posouzení rizika spojeného s matriálem technických zařízení $\mathrm{v}$ provozu někdy postačí jedna správně vybraná metoda a jindy je třeba použít metod několik.

Metodami nedestruktivních testů sledujeme zpravidla jedno aktivum, a to technické zařízení, a velikost rizika měříme jeho dopadem na vybrané parametry materiálu (kumulace a množství trhlin, intenzity magnetické intenzity).

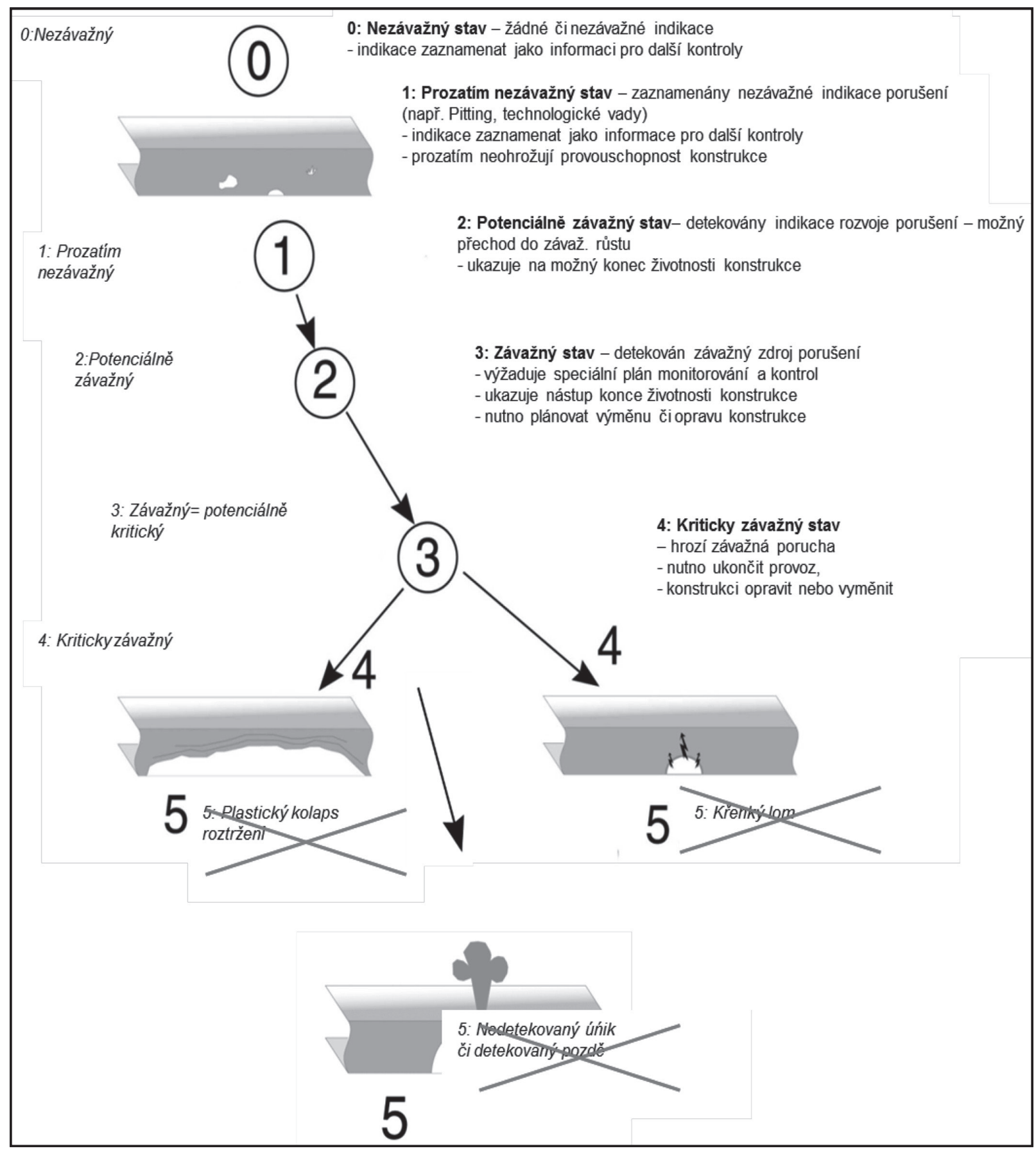

Obr. 2 Vztah stavu materiálu a selháni technického zařizení [14].

Fig. 2 Material conditions and technical equipment failure [14]. 


\section{Stav materiálu technického zařízení a jeho příspěvek k selhání zařízení}

Každé technické zařízení umístěné v provozu má jistý úkol, který musí splnit bezpečně, tj. spolehlivě, a přitom neohrozit sebe a své okolí [1,10-13]. Je faktem, že každé problémy v materiálu, ze kterého je složené, ovlivňují plnění tohoto úkolu. Zkušenosti ukazují, že se tak děje až od určité velikosti problémů.

Na obr. 2 [14] je ukázán vztah mezi stavem materiálu technického zařízení a selháním technického zařízení, přičemž ke klasifikaci velikosti rizika je použita kategorizace 0 až 5 , což je v souladu s praxí ve světě [10].

Obr. 2 ukazuje, jak rozvoj defektů přispívá postupně k riziku. Jestliže defekty překročí bezpečnostní limity, tak dojde k realizaci rizika. Výsledkem je potom selhání technického zařízení, což u kritických zařízení, kterými jsou např. tlakové nádoby, produktovody se stlačenými nebezpečnými látkami apod. znamená havárii.

Dále v práci ukážeme výsledky dvou metod, a to:

- metoda založená na měření akustické emise,

- metoda založená na magnetické paměti materiálu.

Obě metody slouží ke zjišt'ování integrity materiálu, k detekci trhlin, ke sledování vzniku a rozvoje trhlin, k monitorování těsnosti systémů (úniky), k detekci materiálových vad tlakových zařízení či jednotlivých komponentů, k vyhodnocení fyzikálních procesů probíhajících v materiálu, ke sledování kritických míst tlakových nádob, potrubí a konstrukcí, ke sledování procesů při únavových materiálových zkouškách a destrukčních testech.

\section{PŘÍKLAD APLIKACE METODY AKUSTICKÉ EMISE}

Defekty v materiálu se při zatížení projevují vyzařováním elastických vln; předmětný jev označujeme jako akustická emise. Principem metody akustické emise je „odposlech“ a vyhodnocení procesů probíhajících v materiálu během zatěžování technického zařízení, tedy při tlakových zkouškách nebo za provozu. U sledovaného technického zařízení se na vytypovaná místa rozmístí snímací sondy ( $\mathrm{v}$ prrípadě horkého tělesa se na povrch navaří tzv. vlnovody procházející izolací a sonda se montuje na jejich konce). Sonda je přes předzesilovač signálu a koaxiální kabel připojena na analyzátor vln a řídící počítač, umístěné $\mathrm{v}$ bezpečné vzdálenosti. Jako pomocná veličina je zaznamenáván tlak, př́ípadně teplota. Naměřená data jsou nahrávána do počítače k dalšímu zpracování (vyhodnocování).

Dále uvedený př́iklad ukazuje měření akustické emise v Unipetrolu, jehož cílem bylo posouzení integrity tělesa tlakové nádoby z austenitu a identifikace prípadných zdrojů emisí, které by svojí charakteristikou odpovídaly aktivním defektům a které mohly vzniknout v důsledku působení provozních zatěžovacích parametrů během dlouhodobého provozu. K testu tlakové nádoby došlo proto, že u ní byla opakovaně za provozu detekována netěsnost, a proto vzniklo podezření, zda tato netěsnost není způsobena průchozím defektem typu trhliny v materiálu tělesa tlakové nádoby, k jejímuž rozevírání dochází v průběhu změny zatěžovacích parametrů při náběhu na provozní parametry - tlak do 3,3 $\mathrm{MPa}$, teplota cca $-160^{\circ} \mathrm{C}$.
$\mathrm{Na}$ vnějším povrchu nádoby byla rozmístěna sít' snímačů akustické emise zahrnující celý objem nádoby [15]. V normálním provozu daná tlaková nádoba pracuje v kryogenních podmínkách $\left(-160{ }^{\circ} \mathrm{C}\right)$. Při vlastní tlakové zkoušce dusíkem byla registrovaná zvýšená emisní aktivita, zejména ve válcové části nádoby [15]. Jednotlivé emisní události nebyly lokalizovány do dílčích zdrojů (klastrů), ale byly rozloženy v celém objemu pláště. Předmětná skutečnost způsobila komplikace při hodnocení stavu tlakové nádoby dle stávajících platných norem pro hodnocení signálů akustické emise.

Další analýzou bylo zjištěno, že se jedná o registrované signály akustické emise vyvolané fázovou transformací austenitu na deformační indukovaný martenzit, včetně reverzního procesu v lokálních místech. Proto bylo provedeno měření akustické emise, které bylo realizováno při náhradní tlakové zkoušce dusíkem. Výsledky měření byly zpracovány pro tlakovou nádobu ve formě mapy plošné lokalizace emisních událostí na rozvinutém plášti a časových průběhů emisní aktivity, amplitudy EU a tlaku, obr. 3.

$\mathrm{Na}$ obr. 3 jsou body zobrazeny lokalizované události akustické emise; jsou odlišeny barevně, od barvy modré> světle modré $>$ zelené > oranžové > po červenou; nejzávažnější mají barvu červenou. Na obr. 3 vidíme místa:

- s vysokými lokálními koncentracemi aktivity (hustoty bodů),

- s vysokou intenzitou událostí (sytost barvy).

Shluky událostí akustické emise (především pak ty s červeným či oranžovým jádrem) označují lokálně koncentrované zdroje událostí akustické emise; fialově jsou označena místa s instalovanými snímači akustické emise [15].

Při vyhodnocování naměřených dat bylo vzato v úvahu, že na nádobě byl v krátkém časovém horizontu před měřením akustické emise aplikován větší počet zatěžovacích tlakových

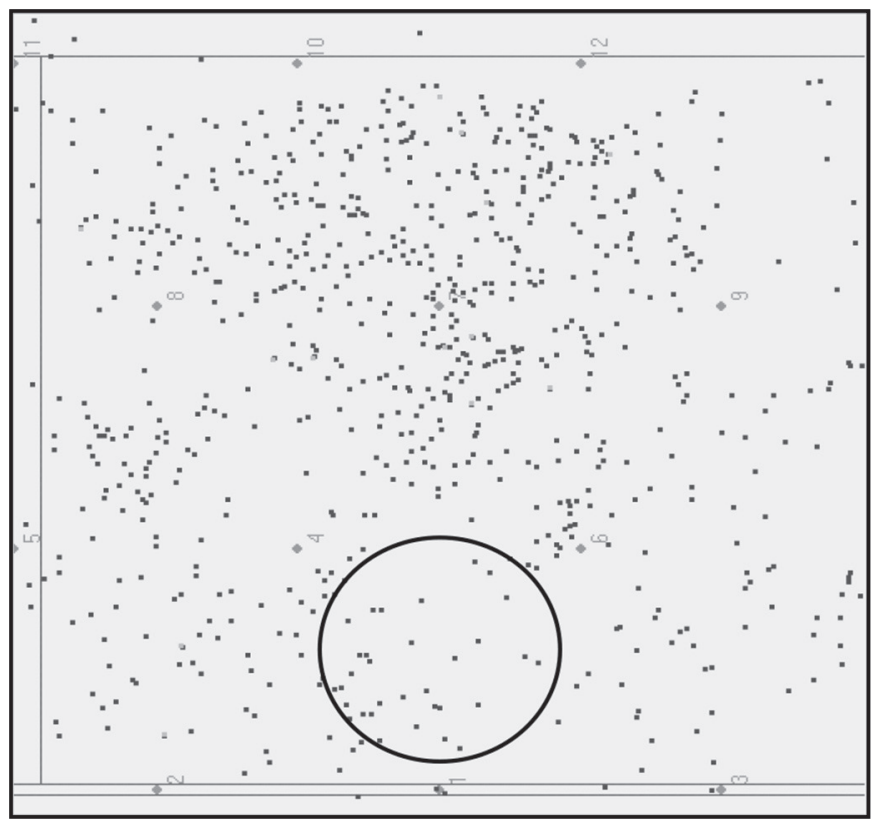

Obr. 3 Mapa lokalizovaných emisnich událostí ve válcové ćásti nádoby prri tlakováni s prodlevou na maximálním tlaku [15].

Fig. 3 Map of localized emissions events in the cylindrical part of the vessel at the pressurization with a delay on the maximum pressure [15]. 


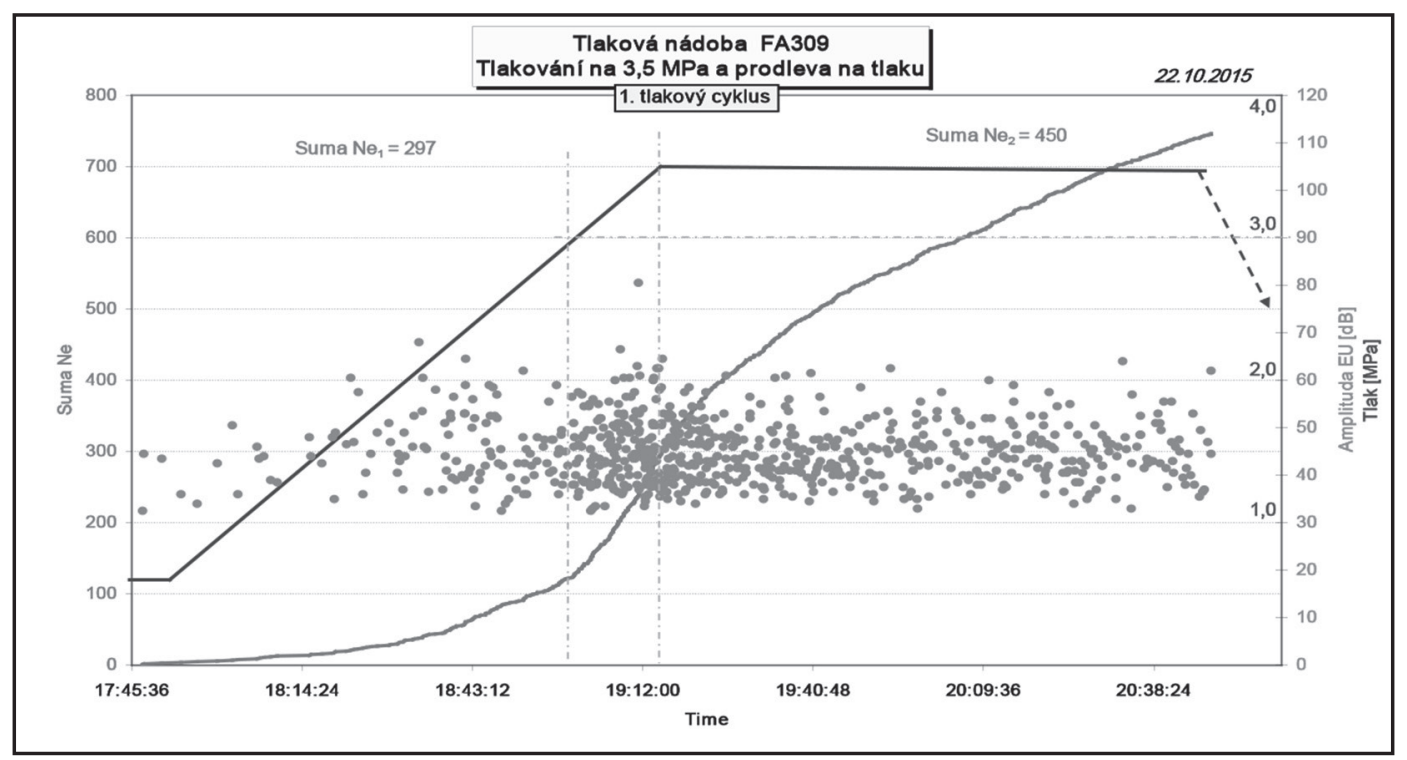

Obr. 4 Časový průběh emisni aktivity na válcové části nádoby - 1. cyklus [15].

Fig. 4 The time course of emission activity on the cylindrical part of vessel-1. cycle [15].

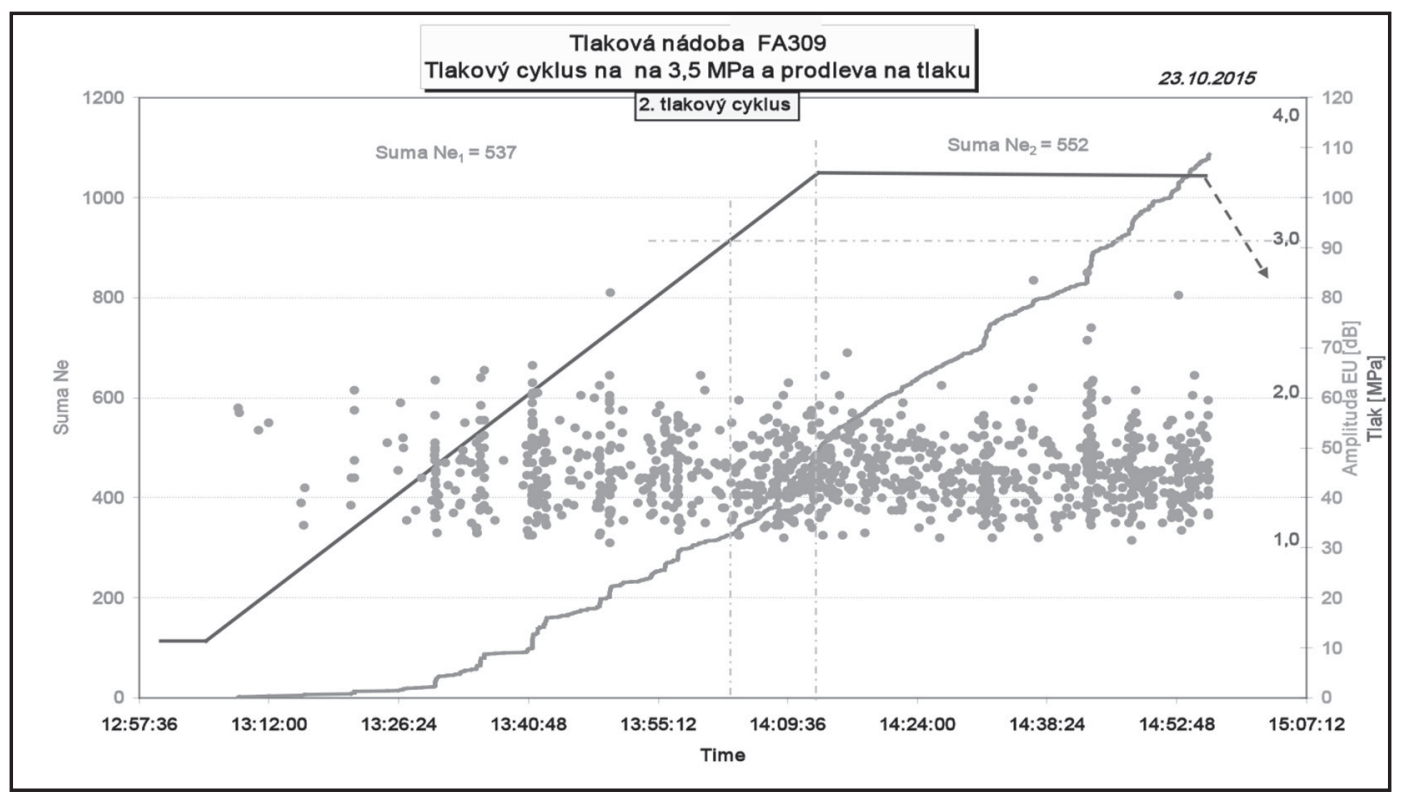

Obr. 5 Časový průběh emisní aktivity na válcové části nádoby - 2. cyklus [15].

Fig. 5 The time course of emission activity on the cylindrical part of vessel-2. cycle [15].

cyklů na tlak 3,5 a 4.0 MPa při těsnostních tlakových zkouškách, souvisejících s opakovaným náběhem po identifikaci netěsnosti a při jejím hledání pomocí héliového testu.

Měření časového průběhu akustické emise bylo provedeno dvakrát; výsledky ukazují obr. 4 a 5.

Z časových průběhů emisní aktivity je patrné, že zvýšená četnost emisní aktivita nastává po překročení tlaku 2,8 až 3,0 MPa. Většina emisních událostí vykazuje nízkou až střední intenzitu a nízký počet intenzivních emisních událostí s amplitudou nad $60 \mathrm{~dB}$ není koncentrován do emisních zdrojů.

Z map lokalizace a časových průběhů emisní aktivity [15], emisní události byly v obou tlakových cyklech lokalizovány po celém povrchu válcové části; větší hustota byla v horní polovině. Výsledky lokalizace míst vzniku akustické emise v obou tlakových cyklech tudíž nepotvrdily koncentraci emisních událostí do ostrých lokálních emisních zdrojů se zvýšenou četností a intenzitou emisních událostí, které by ukazovaly na možný lokální pevnostní problém materiálu tělesa tlakové nádoby, tj. prítomnost aktivních defektů typu trhlina [15].

Přestože výsledky měření obou tlakových cyklů nepotvrdily lokalizaci lokálních emisních zdrojů, je vysoká emisní aktivita v obou tlakových cyklech a její nárůst i v obou prodlevách porušením Kaiserova efektu [16], který představuje významné kritérium pro posuzování závažnosti emisní aktivity a lokálních emisních zdrojů, zejména s ohledem na již dříve aplikované tlakové cykly. Proto i přes absenci lokálních emisních zdrojů, emisní aktivita na válcové části klasifikována v souladu s normou ČSN EN 14548 jako závažná, resp. podle četnosti a intenzity emisní 
aktivity v obou prodlevách klasifikována stupněm 3 - „Kriticky závažná“, což znamená, že u tlakové nádoby je již velké nebezpečí, že dojde k porušení; tj. výše rizika je velká. Proto bylo provozovateli doporučeno, aby zavedl častější inspekce a zvýšil četnost a kvalitu údržby, aby nedošlo k narušení bezpečnosti [15].

\section{PŘÍKLAD APLIKACE METODY MAGNETICKÉ PAMĚTI MATERIÁLU}

Magnetická pamět' materiálu je jev, který nastává v materiálu ve formě zbytkové magnetizace, ke které dochází vlivem procesu výroby, tepelného zpracování, ochlazování, tváření, ohýbání, tvarování, lisování, sváření apod. v prostředí zemského magnetického pole a vlivem provozního zatížení. Principem metody je skenování intenzity magnetického pole Hp těsně nad povrchem materiálu pomocí skenovacího zařízení - jde o vozíček, na kterém jsou upevněny snímací sondy, opatřený kolečky pro snímání vzdálenosti lx a př́slušnou elektronikou pro zesílení a digitalizaci signálů ze sond. Při měření se sledují hodnoty intenzity Hp, nebo gradientu magnetického pole $\mathrm{dHp} / \mathrm{dx} \mathrm{v}$ číselné nebo grafické podobě (tzv. Magnetogram).

Příklad, který budeme dále sledovat, ukazuje výsledky měření stavu ocelových podpěr pod mosty (pižmy), které se používají při stavbě mostů, které se nachází ve skladu v Bošanech [15]. Bylo použito měřící zařízení TSC-7M-16, skenovací zařízení 2M-219,

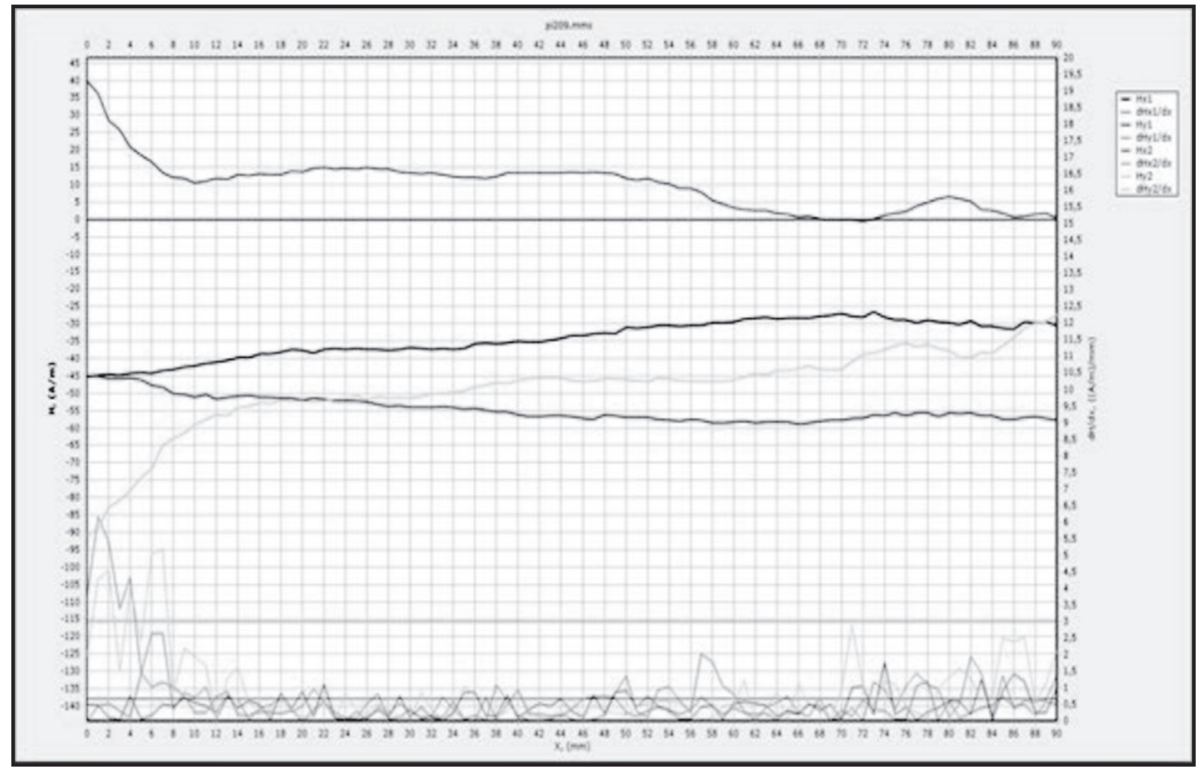

Obr. 6 Př̀iklad svaru, kde nebyly nalezeny zóny koncentrace napětí [15].

Fig. 6 Example of weld where the stress concentration zones were not found [15].

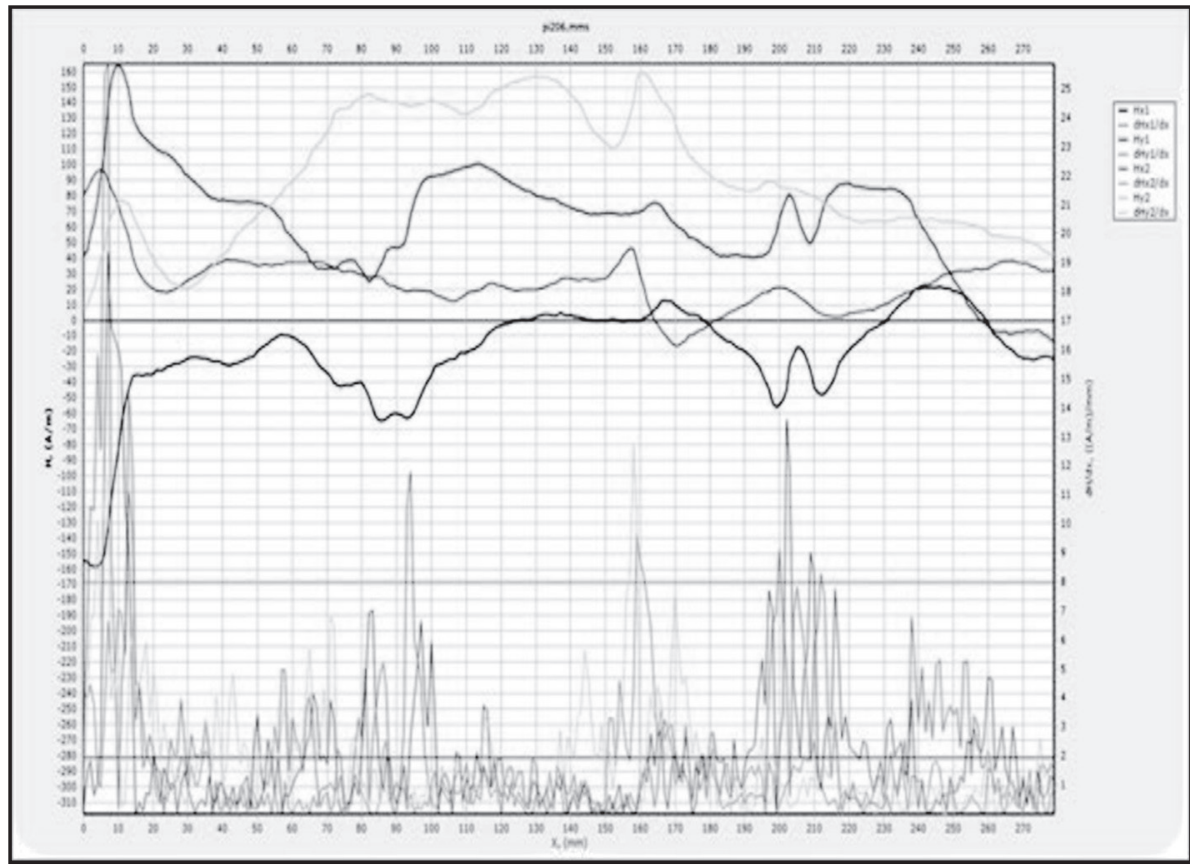

Obr. 7 Př́klad svaru, kde jsou viditelné zóny koncentrace napětí [15].

Fig. 7 Example of welding in which stress concentrations zones are visible [15]. 
systém SW MMM 4 a vyhodnocovací software. Byl kontrolován stav svarů.

Obr. 6 ukazuje př́klad svarů, na kterém nebyly nalezeny žádné zóny koncentrace napjatosti; průběhy magnetické intenzity měřené po svaru nevykazují žádné výrazné výkyvy.

Obr. 7 ukazuje př́klad svarů, kde jsou viditelné zóny koncentrace napětí; vidíme výrazné výkyvy hodnot magnetické intenzity, což znamená závažnou poruchu materiálu. Tento případ byl ještě ověřen metodou vířivých proudů. Jelikož závažnost byla potvrzena, tak ke zlepšení stavu svarů byla přijata technická opatření [15].

\section{ZÁVĚR}

Pro bezpečnou společnost s potenciálem rozvoje jsou nutná bezpečná technická zařízení od malých až po velké rozměry o různé složitosti. Je třeba optimálně rrídit jejich bezpečnost, což lze jen řízením prioritních rizik [11]. V rrízení rizik velkou roli hraje rozhodnutí, zda riziko je přijatelné, podmíněně přijatelné, anebo nepřijatelné [1,10-12]. Pro posouzení jsou třeba data.

V práci jsou ukázány dopady rizika, které souvisí s opotřebením technického zařízení, zjištěné nedestruktivními metodami, a to měřením akustické emise a měřením magnetické paměti materiálu. Příklady ukazují zřetelně místa na technických zařízeních, ve kterých jsou defekty v materiálu, a umožňují určit i jejich rozsah. Tím dovolují správně rozhodnout o riziku, které je spojeno se stavem materiálu technického zařízení, což umožňuje správně vybrat následná opatření na zvýšení či alespoň udržení stávající úrovně bezpečnosti.

Ačkoliv defektoskopická a diagnostická činnost nepřináší v ekonomickém pojetí bezprostřední zisk vlastníkům výrobních zařízení, je důležitá, protože umožňuje včasnými zásahy předejít selháním důležitých technických zařízení, která mohou zapř́íčinit velké havárie, a tím i ztráty lidských životů, škody na majetku a životním prostředí, ztrátu konkurenceschopnosti a dobrého jména provozovatele, a v mnoha př́padech poškodit i celý region tím, že budou chybět výrobky, zvýší se nezaměstnanost, což povede $\mathrm{k}$ dalším nežádoucím jevưm.

\section{LITERATURA}

[1] PROCHÁZKOVÁ, D. Analýza, řizení a vyporádání rizik spojených s technickými dily. ČVUT, Praha, 2018, $222 \mathrm{~s}$. ISBN 978-80-01-06480-1. http://hdl.handle.net/10467/78442

[2] PROCHÁZKOVÁ, D., PROCHÁZKA, J. Data a metodika jejich zpracováni pro potřeby inženýrských disciplín. ČVUT, Praha, 2015, 186 s. ISBN: 978-80-01-05792-6.

[3] RAMUHALLI, P., HENAGER C. H., GRIFFIN, J. W., MEYER, R. M., COBLE, J. B., PITMAN, S.G., BOND, L. J. Material Aging and Degradation Detection and Remaining Life Assessment for Plant Life Management. IAEA-CN-194-1P28. www.inis.iaea.org

[4] BOND, L. J., et al.: Damage Assessment Technologies for Prognostics and Proactive Management of Materials Degradation (PMMD). Nuclear Technology, 173(46), pp. 99-152.

[5] KREINDL, M., ŠMÍD, R.: Technická diagnostika. BEN, Praha, 2006, 466 s. ISBN 80-7300-158-6.

[6] GAJDOŠ, L. a kol. Spolehlivost plynovodních potrubí. ČVUT, Praha, 2000, 217 s. ISBN 80-01-02143-2.

[7] CHEVILEND, R. Inzhenernaya nadezhnost i rasthet na dolgovecznost. Energia, Moskva 1966, $232 \mathrm{~s}$.

[8] MBA, D. U., RAO, R. B. K. N. Condition Monitoring and Diagnostic Engineering Management. University Press, Granfield, 2006, 649 p. ISBN 1-871315-91-3.

[9] KOPEC, B. a kol. Nedestruktivní zkoušení materiálů a konstrukci. CERM, Brno, 2008, 571 s. ISBN 978-80-7204-591-4.

[10] PROCHÁZKOVÁ, D. Bezpečnost složitých technologických systémů. ISBN: 978-80-01-05771-1. Praha: ČVUT 2015, 208p.

[11] PROCHÁZKOVÁ, D. Zásady ř́zení rizik složitých technologických zařizeni. ČVUT, Praha, 2017, 364 s. e-ISBN 78-80-01-06182-4. http://hdl.handle.net/10467/72582

[12] PROCHÁZKOVÁ, D. Základy ř́zení bezpečnosti kritické infrastruktury. ČVUT, Praha, 2013, 223 s. ISBN 978-80-01-05245-7.

[13] PROCHÁZKOVÁ, D. Strategické řizení bezpečnosti území a organizace. ČVUT, Praha, 2011, 483p. ISBN: 978-80-01-04844-3.

[14] SVOBODA, V. Vznik a rozvoj defektů a jejich přispěvek k riziku. Archiv. Preditest, Praha.

[15] PREDITEST: Archiv. Preditest, Praha, 2019.

[16] API. RP 581, Risk-Based Inspection Technology, Section 7 Pressured Relief Devices, American Petroleum Institute (API) Recommended Practice 581, $2^{\text {nd }}$ Ed., September 2008.

[17] PROCHÁZKOVÁ, D; SVOBODA, V. Výsledky nedestruktivních metod podporujících rozhodování o riziku. In: Sbornik př̀spěvků konference Expert Forensic Science Brno 2019. Ústav soudního inženýrství Vysokého učení technického v Brně, 2019, s. 574-587. ISBN 978-80-214-5708-9.

\section{Správná citace:}

PROCHÁZKOVÁ, D., SVOBODA, V. Výsledky nedestruktivních metod podporujících rozhodování o riziku. Soudní inženýrství, 2019, 30(2), 32-39. DOI: http://dx.doi.org./10.13164/SI.2019.2.32. ISSN 1211-443X. 